\title{
EVALUASI KEBIJAKAN SEKTOR KONSTRUKSI PROPINSI PAPUA BARAT DALAM MENGHADAPI PASAR TUNGGAL ASEAN 2015
}

\author{
Hendrik Pristianto, ST., MT. ${ }^{1}$ \\ ${ }^{I}$ Peneliti LPJK Propinsi Papua Barat, email : tekniksipilsorong@gmail.com
}

\section{A. Pentingnya Dukungan Kebijakan Sektor Konstruksi di Daerah Dalam Menghadapi Pasar Tunggal ASEAN}

1. Amanat Undang-Undang Nomor 18 Tahun 1999 pasal 35 tentang Jasa Konstruksi dan Peraturan Pemerintah Nomor 30 Tahun 2000 tentang Penyelenggaraan Pembinaan Jasa Konstruksi, yaitu perlunya upaya pembinaan yang meliputi pengaturan, pemberdayaan, dan pengawasan terhadap masyarakat jasa konstruksi. Hal tersebut dapat dilakukan oleh Pemerintah, Pemerintah Provinsi, Pemerintah Kabupaten/Kota sesuai dengan kewenangan masing - masing.

2. Sebagai sarana menjalankan amanat undang undang tentang jasa konstruksi, maka untuk wilayah Papua yang terdiri dari Provinsi Papua dan Provinsi Papua Barat sangat diperlukan adanya Peraturan Daerah Provinsi (PERDASI) mengenai Jasa Konstruksi yang didalamnya mengatur agar layanan jasa konstruksi di daerah ini dapat berlangsung dengan kompetisi yang sehat, dengan mengedepankan kompetensi badan usaha yang ada.

3. Pada tahun 2015, kawasan ASEAN akan menjadi pasar terbuka yang berbasis pada produksi, dimana aliran barang, jasa dan investasi akan bergerak bebas, sesuai dengan kesepakatan ASEAN. Disebutkan dalam Road Map for an ASEAN Community bahwa 3 (tiga) cetak biru Masyarakat ASEAN yaitu (1) politik -keamanan, (2) ekonomi dan (3) sosial budaya. Dalam hal ini, Indonesia harus memanfaatkan integrasi regional yang tertuang dalam rencana aksi dan target waktu hingga tahun 2015 (Asean Economic Community/AEC 2015) dengan empat elemen pilar AEC Blueprint / cetak biru Masyarakat Ekonomi ASEAN (MEA 2015) yaitu pasar tunggal dan basis produksi regonal, kawasan berdaya-saing tinggi, kawasan dengan pembangunan ekonomi yang merata, dan integrasi dengan perekonomian dunia.

4. Salah satu pilar cetak biru Masyarakat Ekonomi ASEAN 2015 yaitu pasar tunggal ASEAN 2015 jika dikaitkan dengan pembangunan di tanah Papua (Propinsi Papua dan Propinsi Papua Barat) salah satunya dijembatani dengan adanya Peraturan Presiden RI Nomer 65 Tahun 2011 tentang Percepatan Pembangunan Propinsi Papua dan Propinsi Papua Barat. Proses dan langkah-langkah yang dilakukan dalam upaya Percepatan Pembangunan Propinsi Papua dan Propinsi Papua Barat sudah banyak, namun saat ini diperlukan program yang cepat diwujudkan, konkrit dan 
dapat segera dirasakan manfaatnya oleh masyarakat Papua dan Papua Barat. Maka disusunlah Rencana Aksi Percepatan Pembangunan Propinsi Papua dan Propinsi Papua Barat (P4B) Tahun 2011-2014. Khusus untuk Propinsi Papua Barat, ditetapkan ada 10 program strategis dan salah satunya terkait sektor konstruksi yaitu pembangunan dan pengembangan infrastruktur dasar yang menopang kegiatan ekonomi masyarakat.

5. Surat MENDAGRI 601/476/SJ tanggal 13 Maret 2006 kepada selurh Gubernur dan Bupati di Indonesia perihal penyelenggaraan jasa konstruksi di daerah. Untuk rnaksud tersebut di atas diharapkan Pemerintah Provinsi dan Pemerintah Kabupaten/Kota dapat menerbitkan Keputusan Kepala Daerah untuk menetapkan Unit Kerja Pembina Jasa Konstruksi

\section{B. Kondisi Eksisting Pengelolaan Jasa Konstruksi di Propinsi Papua Barat}

Dari hasil penelitian ini didapatkan informasi bahwa :

a. Sebaran Kontraktor di Propinsi Papua Barat berdasarkan kualifikasi badan usahanya dapat dilihat pada gambar di samping. Dari gambar terlihat bahwa mayoritas kontraktor di

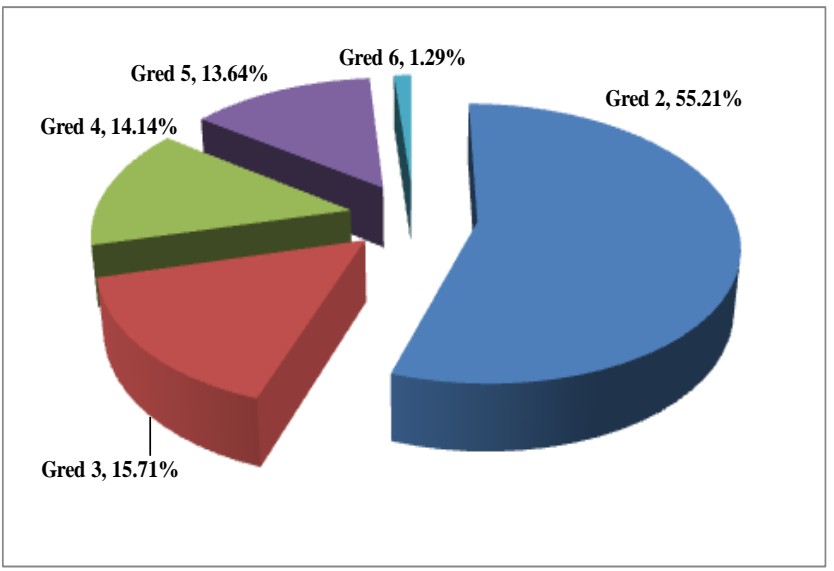
Propinsi Papua

Barat berada pada kualifikasi Gred 2, yang berarti pada kategori pengusaha kecil.

b. Ketersediaan kebijakan sektor konstruksi di Papua Barat hanya terbatas berupa Undang-Undang, Peraturan Pemerintah ataupun Peraturan Presiden. Artinya semua berasal dari Pemerintah Pusat. Sedangkan Pemerintah Propinsi Papua Barat belum mempunyai peraturan tertulis pada sektor konstruksi. Gambar di bawah ini merupakan kondisi eksisting ketersediaan kebijakan tertulis pada sektor konstruksi di Propinsi Papua Barat

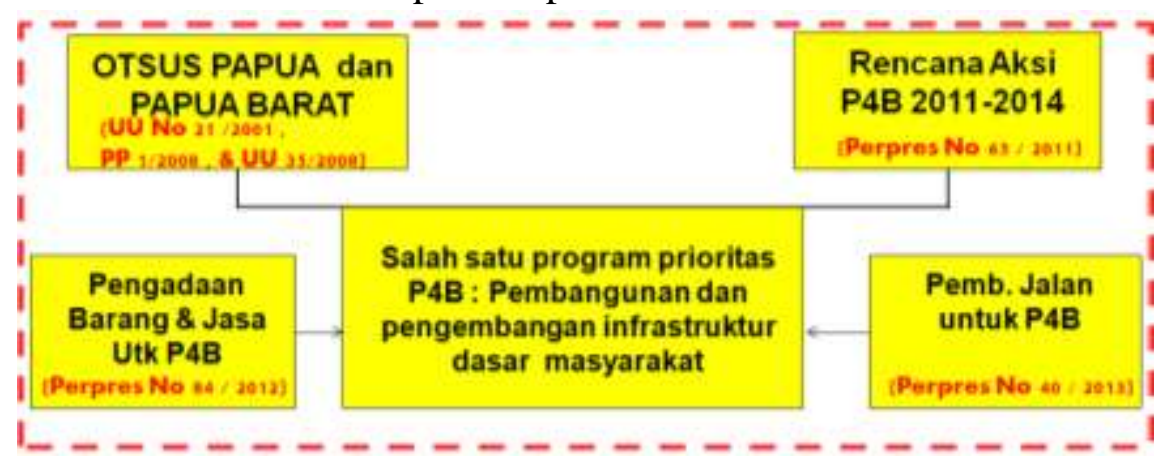




\section{Isu Strategis Sektor Konstruksi di Propinsi Papua Barat Dalam Persiapan Menghadapi Pasar Tunggal ASEAN 2015}

Sebagaimana diuraikan pada awal paper ini, bahwa sektor konstruksi di Propinsi Papua Barat dikelola berdasarkan Kebijakan dari Pemerintah Pusat yang dikhususkan untuk Propinsi Papua Barat, antara lain :

1. UU Nomor 21 Tahun 2001 tentang Otonomi Khusus untuk Propinsi Papua, pasal 62 ayat 2 : " Orang asli Papua berhak memperoleh kesempatan dan diutamakan untuk mendapatkan pekerjaan dalam semua bidang pekerjaan di wilayah Provinsi Papua berdasarkan pendidikan dan keahliannya"

2. Perpres Nomor 65 Tahun 2011 tentang Rencana Aksi Percepatan Pembangunan Propinsi Papua dan Papua Barat (P4B) tahun 2011-2014. Sinkronisasinya Perpres 65 Tahun 2011 dengan UU Otsus dalam sektor konstruksi adalah diusungnya beberapa program prioritas, salah satunya adalah menyentuh aktifitas fisik yaitu pembangunan dan pengembangan infrastruktur dasar masyarakat Papua. Untuk mengawal sinkronisasi tersebut, maka diterbitkan :

a. Perpres Nomor 84 Tahun 2012 tentang Pengadaan Barang dan Jasa Pemerintah Dalam Rangka Percepatan Pembangunan Propinsi Papua dan Papua Barat (P4B). Kebijakan ini dimaksudkan untuk memberikan kesempatan dan peran yang lebih besar kepada orang asli Papua dalam pengadaan barang/jasa pemerintah yang dilakukan di wilayah Propinsi Papua dan Papua Barat, yang memuat beberapa pengecualian yang bersifat khusus dari Perpres 54 Tahun 2010, sebagimana telah dua kali diubah terakhir dengan Perpres Nomor 70 tahun 2012.

b. Perpres Nomor 40 Tahun 2013 tentang Pembangunan Jalan Dalam Rangka Percepatan Pembangunan Propinsi Papua dan Papua Barat (P4B). Kebijakan ini dimaksudkan untuk membuka keterisoliran wilayah guna menghubungkan satu lokasi dengan lokasi lainnya yang mempunyai kondisi geografis yang sulit/berat, sehingga dapat memperlancar arus orang dan barang.

Dalam hal ini, komposisi orang asli Papua yang aktif dalam kegiatan sektor konstruksi dapat dilihat pada gambar samping ini. Data ini penting ditampilkan, bukan untuk membuat sekat antara putra daerah dan non putra daerah, tapi ini lebih pada untuk memperjelas posisi dan besaran komunitas subjek kebijakan yang dievaluasi.

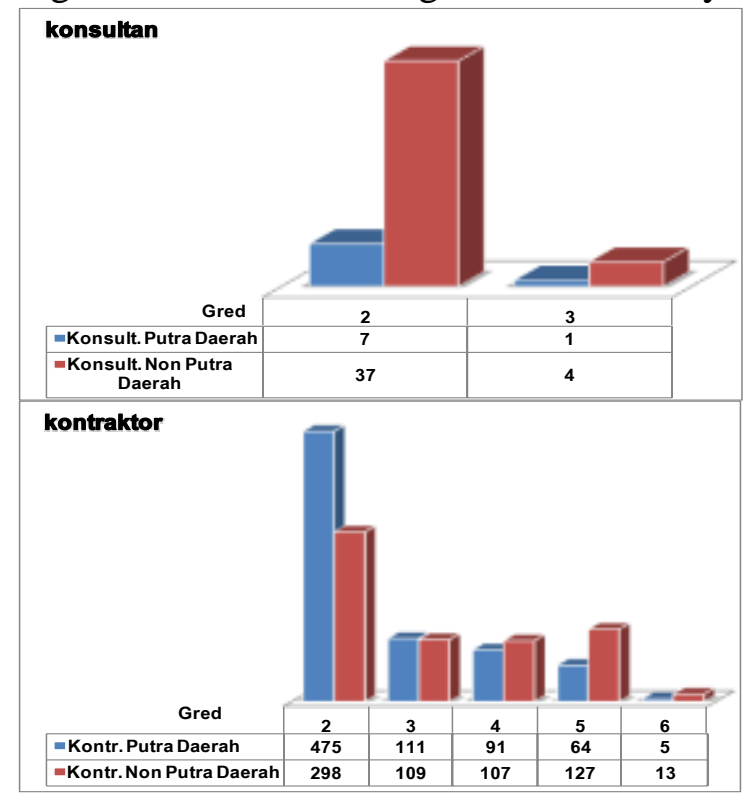


Oleh karena itu, yang akan kita evaluasi secara mendalam adalah implementasi dari Perpres 84 Tahun 2012 dan Perpres 40 Tahun 2013. Aspek yang dievaluasi untuk mengetahui kesenjangannya sesuai dengan tahapan pada Regulatory Gap Analysis (RGA) adalah kriteria efektifitas,efisiensi, kecukupan, perataan dan responsivitas. Dari analisa data dengan metode RGA tersebut, dapat disimpulkan bahwa :

1. kebijakan sektor kontsruksi yang telah ada dan berlaku di Propinsi Papua Barat BELUM BISA MENJAWAB permasalahan yang menjadi latar belakang dibuatnya kebijakan tersebut.

2. Selama ini, beberapa pengelola proyek konstruksi mengambil kebijakan pada setiap satuan kerja untuk menjawab permasalahan yang belum diatur khususnya pada Perpres 84 tahun 2012, yaitu masalah PEMERATAAN PAKET PEKERJAAN untuk pengusaha kontraktor putra daerah.

3. Sedangkan jika pemerataan itu sendiri diartikan oleh subjek kebijakan, bahwa mereka semua harus mendapatkan jatah pekerjaan setiap tahunnya. Anggapan itu diyakini sebagai implementasi dan hak mereka yang diatur dalam Perpres 84 tahun 2012. Padahal, faktanya bahwa jumlah paket pekerjaan yang ada tidak sebanding dengan jumlah kontraktor putra daerah.

4. Hal inilah yang mendesak untuk dibuatkan payung hukum di daerah (kebijakan di tingkat Propinsi ataupun Kabupaten/Kota di Papua Barat) yang menjadi dasar keseragaman pengelolaan sektor konstruksi sesuai dengan Perpres 84 tahun 2012.

5. Beberapa pihak yang diwawancarai sebagai perwakilan pemerintah daerah, mengusulkan dibuatkan petunjuk teknis dari Perpres 84 tahun 2012, yang nantinya mengatur sistem kompetisi diantara kontraktor putra daerah dalam mendapatkan pekerjaan yang nilai dan besarannya diatur pada pasal 2 Perpres 84/ 2012.

Menyambung hasil analisa kesenjangan di atas, yang menyimpulkan masih dibutuhkannya kebijakan penunjang di Propinsi Papua Barat, sehingga bisa dikatakan isu sentral yang masih harus dikelola adalah ISU PEMERATAAN PEKERJAAN.

Sedangkan mengenai persiapan untuk menghadapi Pasar Tunggal ASEAN, masih perlu ditingkatkan lagi sosialisasinya. Dari beberapa hasil wawancara, pelaku usaha di Propinsi Papua Barat terbagi menjadi 3 persepsinya, yaitu :

1. Sudah memahami bahwa akan ada Pasar Tunggal ASEAN 2015 dan sudah mempersiapkan diri. Persepsi ini diwakili oleh pelaku usaha kualifikasi Besar dan pengurus asosiasi perusahaan konstruksi.

2. Sudah memahami bahwa akan ada Pasar Tunggal ASEAN 2015 akan tetapi masih berharap Proteksi dari Pemerintah dalam persaingan nantinya. Dan mereka masih berharap dapat eksis dengan penerapan Perpres 84 Tahun 2013. Persepsi ini diwakili oleh pelaku usaha kualifikasi Menengah dan Kecil yang merangkap sebagai pengurus asosiasi perusahaan konstruksi.

Belum mengetahui informasi dan secara kelengkapan badan hukum perusahaan belum siap untuk menghadapi Pasar Tunggal ASEAN. Persepsi ini diwakili oleh mayoritas pelaku usaha kualifikasi Kecil. Akan tetapi golongan 
ke 3 ini sangat menuntut haknya yang diatur khususnya dalam Perpres 84 tahun 2012. Mayoritas yang memberikan persepsi ini adalah Pengusaha Putra Daerah. Selain Sistem Proteksi, mereka juga menuntut Sistem Pemerataan Pekerjaan.

\section{Rumusan Konsepsi Kebijakan}

Dalam rangka mendukung pemantapan kesiapan pelaku usaha sektor konstruksi di Papua Barat untuk bersaing pada Pasar Tunggal ASEAN 2015, dibutuhkan beberapa kebijakan, yaitu :

1. Petunjuk Pelaksanaan atau Petunjuk Teknis dari Perpres 84 tahun 2012, yang minimal memuat aturan tentang bagaimana model proteksi yang tepat bagi pengusaha sektor konstruksi golongan kecil di Propinsi Papua Barat.

2. Segera membentuk Tim Pembina Jasa Konstruksi (TPJK) di tingkat kabupaten/ kota sesuai dengan amanat SK Mendagri Nomor 601/476/SJ tanggal 13 Maret 2006 perihal penyelenggaraan jasa konstruksi di daerah. Keberadaan TPJK ini nantinya bisa didorong secara maksimal untuk membantu mensosialisasikan peraturan peraturan terbaru di bidang konstruksi dan membantu pembinaan pelaku usaha di wilayahnya masingmasing. 